\title{
Through the lens of B.Ed. students' self-narratives: The motivational roles of significant others in literacy acquisition
}

\author{
Adelia Carstens \\ University of Pretoria
}

\begin{abstract}
According to the Policy on Minimum Requirements for Teacher Education Qualifications (2011), the acquisition of academic literacies lays the foundation for effective learning in higher education. However, one of the major challenges for designers of academic literacies programmes is to accommodate culturally and linguistically diverse student groups. In response to this challenge the academic literacies curriculum for B.Ed. students overtly draws upon the multiple languages and literacies students bring to the university, using these as a foundation for initiating them into the literacy practices of academia. One of the methods used to operationalise this strategy was to introduce literacy narrative pedagogy, and to gain insight into students' acquisition of literacies by analysing their self-narratives. This article describes students' construction of the identities of significant others in their narratives. New literacy studies serve as the theoretical foundation for the pedagogy, and is used in combination with Selfdetermination Theory as a theoretical framework for the data analysis. The analysis shows that relatedness is the most salient catalyst of motivation in the acquisition of literacies, and parents as well as other primary caregivers feature as the most important sponsors of relatedness. The article concludes with a reflection on the value of the research for curriculum review.
\end{abstract}

Keywords: academic literacies, Bachelor of Education, literacy self-narratives, new literacy studies, significant others, sponsor identities, Self-determination Theory

\section{Introduction}

Literacy self-narratives are autobiographies that focus on language acquisition and literacy (Eldred and Mortensen 1992:513). Traditional literacy narratives portray explicit images of schooling and teaching, particularly in contexts where the narrator is a non-mother tongue 
speaker of English who has successfully crossed language worlds to become an accomplished writer in English. More recently, writing educators have started opening up the writing classroom to multimodal composition (Frost, Myatt and Smith 2009:182) and using methods that engage students in understanding and applying the rhetorical possibilities of different technologies (Frost et al. 2009:181-182). In educational contexts the reading and composition of literacy narratives has become a pedagogical tool to accomplish purposes such as grappling with multilingualism and multiculturalism (Clark and Medina 2000; Williams 2003), building confidence, and bridging the gap between school and community literacies, and the literacies of academia (Corkery 2005).

This article reports on the second analytic phase of a project that was aimed at gauging the effectiveness of Literacy narrative pedagogy in an academic literacy module for Bachelor of Education (B.Ed.) students. The aim of this research phase was to analyse students' literacy selfnarratives with regard to their construction of the identities of significant others, and thereby gain insight into how these significant others may have catalysed or constrained the students' need for freedom of choice, achieving their learning goals, and to feel valued by significant others.

The next section provides the rationale for the study, followed by a theoretical and pedagogical description of the curriculum under consideration. Subsequently, the research design and methodology for the empirical research are outlined. The results of the analysis are discussed under three theory-based thematic categories that draw together different categories of significant others and the various identity roles that students construe for these significant others. The conclusion provides empirically based justification for the current curriculum of the module in question, and offers broad strategies for adapting classroom practice.

\section{Context and rationale}

According to the 'Policy on Minimum Requirements for Teacher Education Qualifications' (DHET 2011:1-12), 'Fundamental learning in the South African context refers to learning to converse competently in a second official language, the ability to use Information and Communications Technologies (ICTs) competently, and the acquisition of academic literacies which lay the foundations for effective learning in higher education contexts [typographical 
emphases as in the original document].' In partial fulfilment of the academic literacy requirement two semester-long academic literacy modules for first-year B.Ed. students, Literacies in Education 110 and 120, were instituted in a faculty of education at a large residential university in South Africa. One of the foundational principles of the curriculum was to draw upon the multiple languages and literacies students bring to the university, while gradually initiating them into the critical reading and composition practices of academia (Carstens, 2012). An overt aim was to counter 'deficit' discourses about students' academic literacy (Lillis and Scott 2007; Turner 2011), and focus on 'diversity' instead of 'disadvantage' (Thesen and Van Pletzen 2006). One of the strategies to counter discourses of disadvantage and deficit was to introduce a fourweek theme on literacy narratives in the academic literacy curriculum. Classroom activities include a discussion of the notions 'literacy' and 'literacies'; reading canonical literacy narratives (for example, Rodrigues 1982); as well as locally produced literacy narratives that reflect the realities of pre- and post-apartheid South Africa (Mgqwashu 2009); group discussions on their understandings of these narratives; an exploration of the lexico-grammatical characteristics of literacy narratives; and the composition of a personal literacy narrative in the format of a multimodal literacy self-narrative, followed by a written narrative essay.

\section{Theoretical and pedagogical foundations of the curriculum}

In Carstens (2012) a theoretical framework for building literacy narrative pedagogy into the academic literacies curriculum for first-year B.Ed. students is proposed. This framework is based on the academic literacies approach, which is closely aligned with the new literacy studies, pioneered by scholars such as Lea (1994) and Street (1995). Apart from embracing socioconstructivism, the academic literacies approach has an overt political agenda, which highlights student identity and agency, institutional relationships of discourse and power, and the contested nature of writing practices (Lillis and Scott 2007). The theoretical foundation also embraces the notion of multiliteracies, as established by the New London Group (2000), which accommodates the multiplicity of communication channels used in present-day communication, as well as linguistic and cultural diversity. Similar to the new literacies, multiliteracies challenge the autonomous view of literacy (Stein and Newfield 2006), recognise the multiplicity of ways in which students make meaning, and promote pedagogies that afford traditional as well as nontraditional students equal opportunities to learn in ways that allow them to participate in public, 
private, community and economic life (Newfield and Maungedzo 2006), use a repertoire of linguistic practices appropriate to different settings, and handle the social meanings and identities that each evokes (Devereux and Wilson 2008). In turn, these multiple ways of learning promote multimodality - an approach that acknowledges and theorises the combination of semiotic modes (image, gesture, oral performance, artistic, linguistic, digital, electronic and graphic) to make meaning (Kress and Van Leeuwen 2006).

The second tier of the framework comprises a model introduced by the new literacies scholars Barton and Hamilton (2000) to accommodate the variety of literacy practices used to make meaning in contemporary society. The model has five main components: literacy practices, literacy domains, literacy events, texts and sponsors: Literacy practices are what people do with literacy, which are regular and patterned by social institutions and power relationships (Barton \& Hamilton 2000). Literacy practices are instantiated by literacy events, in which texts (composed in a variety of semiotic systems) play pivotal roles (Barton and Hamilton 2000). These practices are exercised in literacy domains, such as home, school and the workplace. The actors of the events are termed sponsors, who may enable, support, teach, model, recruit and regulate literacy, but may also suppress or withhold literacy (Brandt 2004). Figure 1 expounds the theoretical and pedagogical framework for the module.

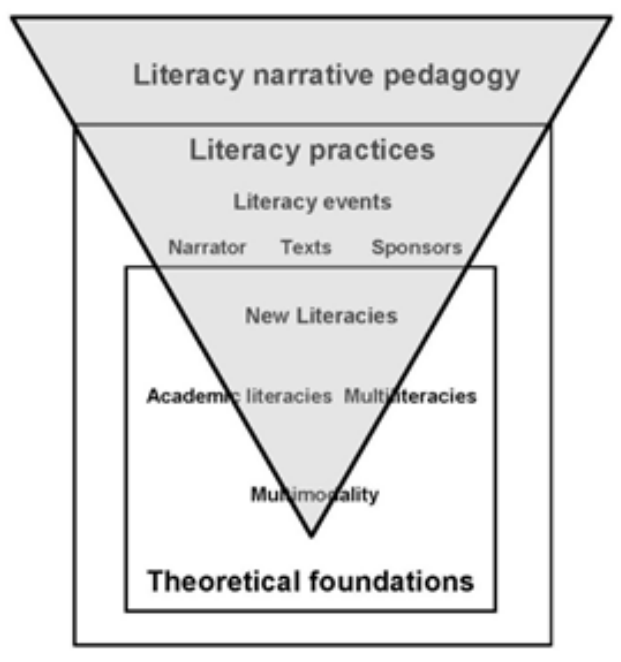

Figure 1: Curriculum framework: syllabus theme on literacy narratives in a first-year academic literacies module for B.Ed. students 
A range of the benefits of including literacy narratives in language learning curricula have been repeatedly mentioned in the literature. These include: guiding students to a more complex understanding of literacy, which is more than simply the ability to read and write (Williams 2003); assisting with confidence building by obtaining proof from published literacy narratives that the transition from home, community and school literacies into more empowering forms of literacy is manageable (Corkery 2005); providing opportunities to reflect on their own literacy identity and literacy practices, and to make conscious choices about how to represent themselves (Coffey 2011; Soliday 1994); as well as helping them to appreciate multiculturalism (Clark and Medina 2000). These benefits are not restricted to successful university study, but are also relevant to becoming a successful teacher in a culturally and linguistically heterogeneous society.

For lecturers, literacy self-narratives may shed light on learners' beliefs and assumptions about learning a particular literacy (Williams 2003; Clark and Medina 2000); as well as the identities that students construe for themselves and significant others. This knowledge may offer lecturers insight into possible student resistance to pedagogical goals and approaches; and assist them to introduce a more dialogical approach to curriculum design and reform (Ball 1989; Clark and Medina 2000; Corkery 2005; Soliday 1994).

In the next section an overview is given of the design of the overarching research project, as well as the outcomes of the first analytic phase, in order to contextualise the second analytic phase.

\section{The overarching research project}

\section{Research questions}

The overarching research project was guided by the question: How can students' literacy selfnarratives inform student-centred curriculum design in an academic literacy module for Bachelor of Education students? Sub-questions included:

1. Which (multi-)literate identities do students construe for themselves in their literacy histories?

2. Which identities do students construe for significant others in their literacy histories?

3. What can lecturers learn from students' literacy narratives to inform the (re-)design of the academic literacy curriculum to accommodate the needs of diverse classes of students? 
Data gathering was done all at once, while data analysis comprised an exploratory phase, followed by two more focused analytic phases: one aimed at understanding students' literacy identities; and another aimed at gaining insight into the roles that sponsors play in shaping these identities.

\section{Data gathering procedure}

After composing a multimodal self-narrative of their (multi-) literate or multilingual histories, students had to compose a written self-narrative in response to the following essay prompt:

Write an essay of 700 to 1000 words telling the story of how you acquired one or more types of literacy that has/have special meaning for you.

All students (a total of 554) submited hard copies to their class lecturers, which were graded according to a rubric. From the total population 153 students (4 groups) were conveniently sampled to submit their essays electronically for research purposes. They were taught by LindaAnne Alston and Yolandi Woest. Alston was responsible for organising the data-collection, soliciting informed consent, and assisting with coding and member-checking, while Woest assisted with coding. Almost 90\% of the students voluntarily signed a letter of consent allowing their essays to be analysed. However, only half of the students submitted essays for analysis. Thus, the electronically submitted essays did not mirror the demographics of the sampled classes. While $62 \%$ of the sample were black and 38\% white, $58 \%$ of those who submitted their essays electronically indicated 'White' as their racial identity. Possible explanations for the low participation rate are a lack of familiarity with using e-mail, and perhaps a lack of confidence in their writing abilities.

\section{Exploratory phase of the data analysis}

The 57 essays were analysed using the qualitative data analysis programme, AtlasTi version 6.1. A partially deductive and partially inductive process was followed. The coders departed from a set of pre-determined codes, which largely coincided with Barton and Hamilton's (2000) categories and sub-categories, as well as a small set of narrator and sponsor codes derived from Williams (2003). The narrator identities mentioned by Williams are hero, child prodigy, victim and rebel. He refers to sponsor identities students construct for their teachers, in particular, and 
although they are said to 'cover a wide range' (Williams 2003:344) he only mentions hero, martinet, nurturer and buffoon. All predetermined codes were recorded and defined in a qualitative codebook, and emergent codes with their definitions were added during the process of constant comparison. The initial coding was done in four cycles by three coders (myself, Alston and Woest), followed by a final moderation round. Some of the a priori codes were eventually discarded, as they did not fit any of the narrators’ constructions of sponsor roles.

\section{Analysis of narrator identities}

The analysis of the students' literacy self-narratives, in terms of the identities they construe for themselves, yielded 18 literacy codes labelling a variety of characteristics that manifest in different literacy events: achiever, confident user, coper, enthusiast, experimenter, failure/fool, insecure learner, learner/developer, multilingual/multiliterate, nerd/geek, perseverer, prodigy, reluctant learner, struggler, sufferer, survivor, teacher, and victim.

Based on the clustering of these micro-identity traits (codes), seven macro-identities (themes), manifesting across language and cultural groups and across literacy practices, were identified using plant names as category labels. Metaphoric labels were chosen to capture the complexity of the constructs more fully. The following macro-identities emerged: dandelion, ivy, resurrection plant, sensitive plant (touch-me-not), Venus fly trap, sunflower and cactus. Carstens and Alston (in press) report in detail on the analysis and interpretation of the data on narrator identities.

\section{Analysis of sponsor identities}

This article focuses on the phase of the analysis dealing with sponsor identities. As input, the emergent sponsor codes identified during the exploratory phase, as described in section 4.3, were used. This process yielded 14 codes, including hero, role model, enhancer, liberator, effective facilitator, motivator, pastor, advisor, peer supporter, trigger, witness, bully, suppressor, bureaucrat, and absent authority.

In addition, 15 codes emerged that label categories of significant others who display the above identity roles in the recounted literacy events: MOTHER, FATHER, PARENTS, BROTHER, SISTER, 
GRANDMOTHER, GRANDFATHER, AUNT, UNCLE, (ENTIRE) FAMILY, (PRIMARY) CAREGIVER, FRIEND, PEER, TEACHER, AND THERAPIST.

Since more than one sponsor role was construed in the majority of literacy narratives it did not make sense to look for clusters of micro-codes that constitute macro-identities. A theoretical framework was needed that could shed more light on the contributions of sponsors to the literacy development of the narrators. Self-determination Theory fitted the profile as it provides explanations for motivation and achievement in contexts of teaching and learning. At a glance it may seem contradictory to use an individualist psychological theory as an analytic framework, while the pedagogy of the intervention is overtly social and critical - using literacy narrative pedagogy framed upon a new literacy studies model. As an alternative, I could have chosen to use theories that approach L2 motivation from a social psychological perspective (Gardner 1985; Dörnyei and Csizér 1998; Cheng and Dörnyei 2007). These theories, however, focus on language learning in particular, and not on the acquisition of multiple literacies inside as well as outside the classroom. Furthermore, educational applications of SDT and the pedagogical strategies developed from the theory are not exclusively focused on influencing individual behaviour. Thus, although the analyses in this article depart from individual narrators' experiences and constructions of reality, situational and contextual factors are invoked where these are relevant to the individual's literacy development.

In the next section an overview is given of Self-determination Theory and its relevance for understanding sponsor identities.

\section{Self-determination Theory as a framework for the analysis of sponsor identities}

According to Self-determination Theory, one of the driving forces behind successful and unsuccessful learning is motivation. Through acting on a person's inherent interests he/she grows in knowledge and skills. According to Ryan and Deci (2000), enjoying the practising of new activities, actively assimilating what has been learnt and applying this knowledge affect performance, persistence and well-being across the different stages of a person's life. However, the activity should in itself be interesting - that is new, challenging or aesthetically pleasing. 
A number of researchers have applied Self-Determination Theory to educational contexts, and have indicated how learning and achievement can be catalyzed or undermined by the practices of significant others, for example Anderman and Anderman (2010), Borg and Al-Busaidi (2011), Ryan and Stiller (1991), Ryan, Stiller and Lynch (1994), and Urdan and Turner (2005). Thus, although intrinsic motivation is the most effective driver in literacy development, also certain forms of extrinsic motivation can be active and agentive. Ryan and Deci (2000:55) reiterate that for certain types of extrinsic motivation 'the extrinsic goal is self-endorsed and thus adopted with a sense of volition'; and if the teacher, parent or other significant person knows how to utilise forms of extrinsic motivation that are active and voluntary, rather than passive and controlling, high-quality learning may indeed take place. The secret then lies in how sponsors, to use the now familiar term, can (a) act to facilitate intrinsic motivation, keeping in mind that environmental factors may also play a role in this regard; and (b) assist students to internalise the responsibility of extrinsic goals and to experience their value in the learning situation. Since educational activities are often not intrinsically interesting, the parent, teacher or other facilitator has to motivate the child/learner to gradually internalize extrinsic reasons for doing necessary, but unappealing activities. In this way agency, without external pressure, and certain values and behavioural patterns are integrated (Ryan and Deci 2000; Urdan and Turner 2005).

According to Self-determination Theory, the basic psychological needs that are satisfied by intrinsically motivated activities, but could be catalysed or inhibited by significant others, include competence, relatedness and autonomy (Ryan and Deci 2000). Below, each of these motivational triggers will be discussed with regard to acquiring literacy.

\section{Competence and literacy learning}

Cognitive Evaluation Theory, a sub-theory of Self-determination Theory, asserts that feelings of competence may enhance intrinsic motivation for a particular action, as they allow satisfaction of the basic psychological need for competence. Students are more likely to adopt and internalize an external goal if they understand it and have the relevant skills to succeed at it (Ryan and Deci 2000). In the literature the term 'self-efficacy' is often used for perceived competence (Bandura 1997). It refers to students' beliefs that they are able to attain 'designated types of performances and achieve specific results’ (Pajares 1996:546). Self-efficacy is task or domain specific, and 
thus a lecturer should use specific procedures to enhance students' self-efficacy for specific tasks. Schunk (1991) lists a number of research-based aspects of self-efficacy that can be addressed by teachers: helping students to set realistic, but somewhat challenging, proximal goals (also compare Ryan and Deci 2000:58); helping students to believe in their cognitive abilities, for instance by giving feedback, which indicates that students are learning and understanding the material; providing models, either by modelling the skills themselves, or by using students who have mastered a task to model the skills; and giving praises and rewards. Such activities are social and constructive, rather than purely individual and cognitive, as they involve learning through interaction between the teacher and the student, as well as among students. Urdan and Turner (2005) as well as and Ryan and Deci (2000) caution teachers against incompetence feedback and demeaning evaluations. Not only may incompetence feedback harm a learner's self-confidence, but also induce feelings of shame through public humiliation.

\section{Relatedness and literacy learning}

Relatedness has to do with a sense of feeling connected to and respected or valued by significant others, such as parents, peer group members, teachers, and society. Parents are the primary attachment figures in as far as they most strongly influence self-related perceptions during early development (Ryan et al. 1994). These perceptions derive, among others, from the question and answer routines that characterise early engagement with picture books. Parents and other primary caregivers thus represent the primary models from which representations (schemata) of subsequent relationships will be derived. Ryan et al. (1994) found that parental representations are correlated highly with those of teachers in predicting school-relevant outcomes: students who feel supported by parents are more likely to experience better relationships with teachers. It is easier for them to relate to teachers, who will usually respond in a reciprocal way. In turn, learners' feelings of relatedness lead to greater perceived control and positive coping (Noddings 1992; Wentzel 1996). These findings resonate with teachers' perceptions about the most important and frequently used motivational strategies in the L2 classroom. Dörnyei and Csizér's (1998) survey among L2 teachers in Hungary indicated creating a pleasant and supportive classroom climate as the second most important motivational classroom strategy from a list of ten, whereas EFL teachers in Taiwan (Cheng and Dörnyei 2007) rated this as the fourth most important motivational strategy. 


\section{Autonomy and literacy learning}

Self-determination Theory indicates that intrinsic motivation will only be enhanced if feelings of competence are accompanied by a sense of autonomy or an internal perceived locus of causality' (Ryan and Deci 2000:57) - thus, if there is a measure of choice and opportunities for self-direction (compare also Borg and Al-Busaidi 2011). Stefanou, Perencevich, DiCintio and Turner (2004) have identified three types of autonomy supportive behaviours in teachers: organizational, procedural and cognitive. Organizational autonomy support has to do with allowing students to make choices regarding the classroom environment; for example choosing group members. Procedural autonomy support manifests when lecturers give students ownership of 'form', such as choosing materials to be used in class projects, and how competence will be displayed. Cognitive autonomy support involves giving students opportunities to feel ownership of their own learning, such as discussing different approaches to solving problems and offering different solutions to problems. As inhibitors of autonomy, Ryan and Deci (2000) mention threats, deadlines, directives and competition pressure, while Urdan and Turner (2005) add interfering with children's natural pace of learning, and not allowing expression of critical or independent opinions. Figure 2 summarises Self-determination Theory and its implications in educational contexts:

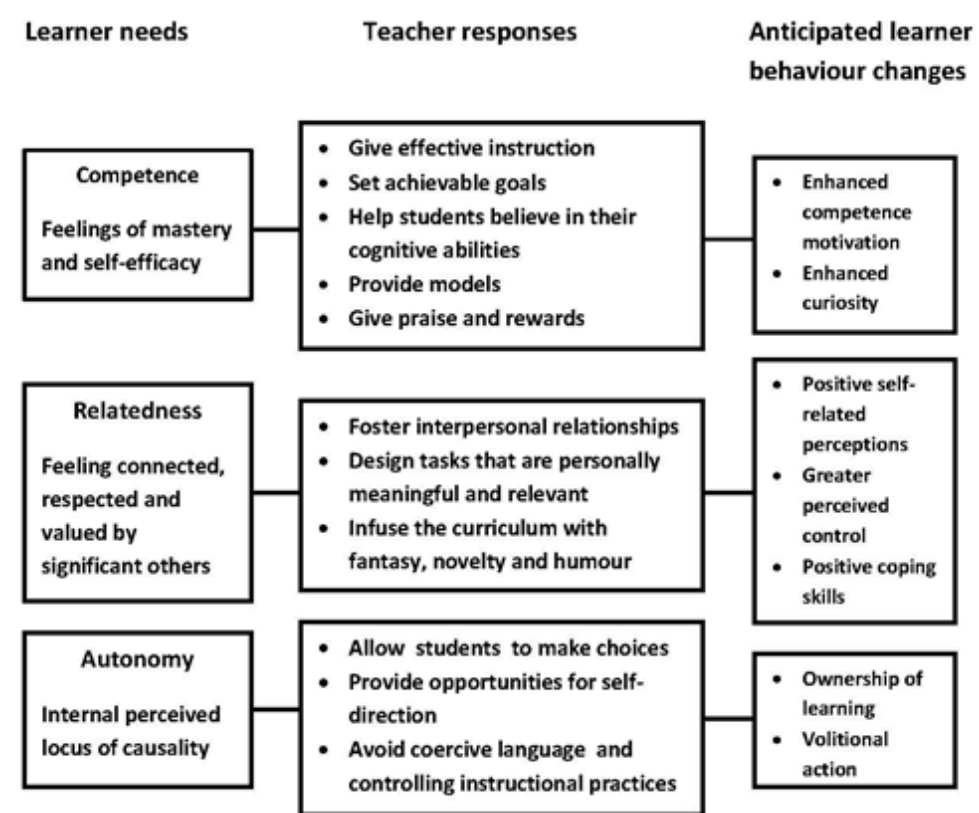

Figure 2: Summary of Self-determination Theory and its implications for educational contexts 


\section{Research methodology}

Research question 2 of the overarching project was formulated as: Which identities do students construe for significant others in their literacy histories? In light of the fact that Selfdetermination Theory was invoked as an explanatory framework at a later stage, it became necessary to break research question 2 up into three sub-questions that would provide insight into the relationships between different categories of sponsors, the identities they assume in literacy events, and how these relate to the three psychological prerequisites for becoming motivated learners:

1. Which categories of significant others feature prominently in promoting, versus inhibiting, competence in learners, and which sponsor identities do they typically assume?

2. Which categories of significant others feature prominently in promoting, versus inhibiting, relatedness in learners, and which sponsor identities do they typically assume?

3. Which categories of significant others feature prominently in promoting, versus inhibiting, learner autonomy, and which sponsor identities do they typically assume?

The data-analysis procedure entailed another cycle of coding, using Self-determination Theory to provide a predetermined set of codes comprising positive and negative sub-codes for each of the categories autonomy, competence and relatedness.

One of the difficult coding decisions centred on pre-literacy events. From a parent's point of view, an activity such as regularly reading bedtime stories to children may be aimed at stimulating competence. However, from the child's perspective, the literacy event may be more salient in terms satisfying his/her need for relatedness. According to Ryan et al. (1994), parents and other primary caregivers are the primary attachment figures, who strongly influence selfrelatedness during early development, which serve as predictors of relatedness with others later in life. Thus, the code positive relatedness was assigned to passages demonstrating preliterate activities that facilitate bonding and instill intrinsic motivation to engage in literacy activities. 
Subsequently, a search query was performed in AtlasTi to list all the codes and quotations for Self-determination, as exemplified by the excerpt below:

P23: Essay 3.rtf - 23:40 [my grade six English teacher ...] (7:7) (Super)

Codes: [Self-determination Theory: competence+] [sponsor: effective facilitator] [significant other: teacher]

my grade six English teacher always encouraged me to read books at home, that way I’d become more familiar with new words and how to spell them. I would underline words I could not read and show them to her, she then helped me to spell it out and then say it, this was an important method of learning for me because it involved two practises, reading and spelling.

The output codes and quotes for each of the notions competence, autonomy and relatedness, were converted to tables (separate tables for positive and negative instances), with columns for coding significant other, sponsor ID and domain. All the emergent codes were subsequently numbered to allow statistical analysis. The numerical codes were transferred to Excel spreadsheets, and with the assistance of a statistician from the Internal Consultation Service of the University's Statistics Department, Lizelle Fletcher, and a data analyst, Jaqui Sommerville, the Excel sheets were converted to cross tables, showing the correspondence between significant others and the sponsor identities they assume in different literacy domains.

\section{Discussion of findings}

The results of the study will be discussed using quantitative salience as a vantage point within the categories of competence, relatedness and autonomy, and supported with evidence and explanations from the qualitative data. Pseudonyms are used to refer to the sponsors populating the students' narratives.

\section{Competence}

After relatedness, with 109 instances, competence was coded 62 times. Contributors of perceived competence are those who help children/learners to set goals, provide the necessary scaffolding 
to attain the goals, help them to believe that they are able to attain the goals, and reward them appropriately if they demonstrate mastery. The TEACHER is construed as the primary contributor of feelings of competence, with 38 codings. He/she acts in the roles of effective facilitator (22 codes), enhancer (10 codes) and motivator (6 codes). Students typically construe the TEACHER as an effective facilitator if they found him/her inspirational, and if they succeeded in their learning goals, as illustrated by essay 58 :

And that is why my high school English teacher insisted that I join the AP (Advanced Program) English class, in this class he encouraged me to read more challenging books than the books I was currently reading-which was mainly teen fiction novels such as Meg Cabot's Princess Diaries-. These “challenging” books included Emily Bronte's Wuthering Heights as well as Leo Tolstoy's Anna Karenina. Because of his encouragement to join his AP English class, I was able to enjoy these classics and move away from the teen novels.

Primary caregivers - various FAMILY members, and CAREGIVER - contributed 15 instances of positive competence. It is interesting to note that in 10 instances the role of effective facilitator was assigned to primary caregivers. Thus, some students construe their PARENTS and other PRIMARY CAREGIVERS as extensions of school, in the sense that they facilitate learning effectively by setting realistic goals and recognise achievement where merited. In essay 60 the narrator relocated from a multiracial Model C school to a rural school where all the learners spoke Sepedi, and she was ridiculed as a 'coconut' because she could not read and write in Sepedi. She construes her AUNT as an effective facilitator in teaching her to read and write in Sepedi, in order to overcome this literacy hurdle:

I made progress with the help of my Aunt who is a foundation school teacher at a primary school adjacent to my high school I the village. My Aunt taught me vowels in Sepedi to reading Sepedi literature.

Although the essay corpus does not feature many examples of incompetence feedback (eight instances), six were attributed to TEACHERS, who are construed as suppressors (4) and bullies (2). 
Essay 23 presents a prototypical example of how TEACHERS' behaviour can instil feelings of incompetence. The narrator, who comes from a literacy deprived home environment, says about his primary school TEACHERS:

[T] he teachers used to tell me that I will never make it in life because this whole world is about reading and then about his high school English teacher: After time passed I went to secondary level that is where I thought I will know how to read but guess what, when my teacher perceived that I cannot read he said to me it is not in his persuit [sic] to teach learners how to read I should have learnt that at primary.

These suppressing prophecies left him devastated and unmotivated to improve his literacy skills, until 'the lady next door' took him under her wing and assisted him to become a more proficient reader.

\section{Relatedness}

Positive relatedness elicited 98 instances of coding, which reveals the salience of feeling connected to significant others. It is not surprising that the word relationship occurs 5 times in word frequency tables generated by AtlasTi for positive relatedness; and the words need/needed/needing occur eight times. In addition, a considerable number of words with strong emotive and attitudinal meanings are listed in the word-frequency tables, including: amazed/amazing, beautiful, cherished, delightful, fantastic, favourite, incredible, love(d), marvel(ous), masterpiece, passionate, significant, spectacular, tremendously. The intensifying adverb very occurs no less than 19 times. Positive relatedness is described through words denoting the attitudes and behaviours of the significant other who fosters relatedness, such as listen/listened/listening (4), inspire/inspired (8), offer(ed) (3), shaped (3), smile(d)/smiling (4), spent + resource (6), support(ed) (8), understand/understood, watch(ed)/watching (6), willing (3); and words denoting learners' responses to relatedness-enhancing behaviours, such as like(d) (8), motivate(d)/motivation (10), thank(ful) (5).

FAMILY members and TEACHERS are the most frequent contributors of feelings of relatedness. Codes for FAMILY members were assigned 51 times, of which MOTHER/MOTHER's/MOM/ 
MOM'S/MOMMY's top the list with 30 occurrences. The most important intersections between significant others and sponsor roles are: FAMILY (especially MOTHERS, GRANDPARENTS and other PRIMARY CAREGIVERS) who act as triggers (19), and motivators (13).

The following three quotes feature FAMILY members acting as triggers:

My father read to me every single night, until one day I started to read the book to him. It was the first time as a child that I saw my father tear up, until this day I remember that moment like it was yesterday. (essay 24)

[M]ost of my childhood I spent with my grandparents, they taught me how to read and write the Punjabi language. My grandmother used to read stories to me in her language. (essay 53)

I would snuggle next to my mother on her bed and she would drift between each sentence pausing for me to stare and marvel at the bright colours of the pictures. In these story time sessions I would be able to escape to another world through my imagination where anything was possible and it was in my control whether negative aspects existed or not. This is where my exciting and marvelous journey began. (essay 54)

In the following excerpts, the PRIMARY CAREGIVER acts as a motivator:

My mother played a huge role in my reading career. She encouraged me to read. She would spend hours on end listening to me read anything that I could find, be it school books or magazines. (essay 38)

She [her GRANDMOTHER] talked to me and explained why I could not go. Although I was young I still remember the way she emphasised the importance of education in my life. "Our current situation will not determine your future my child, in life you must learn to rise above the challenges you face and you will succeed" she would say.

The code TEACHER was assigned 38 times, while the word TEACHER occurs 29 times in excerpts that instantiate positive relatedness. TEACHERS act primarily in the roles of motivator (18 times) and pastor (15 times). Examples of TEACHERS construed as motivators occur in essays 7 and 29: 
One thing that made [me] enjoy reading and communicating was my English teacher, who encouraged me to believe in myself. (essay 7)

I am ever great full for Mr. Van Greunen who taught with great passion, enthusiasm and kept motivating and believing in me. (essay 29)

TEACHERS as pastors are portrayed in the following quotations from essays 26, 38 and 41:

Kristin Young always made me feel good about myself, even when I felt useless. (essay 26)

My grade one teacher, Mrs Nel, impacted my life in a huge way. We instantly clicked the moment we first saw each other and throughout the year formed a deep relationship (essay 38).

Mr Ngobeni noticed her [the narrator's] problem and did his best to help her, He offered to lend her one of the schools old computers (essay 41).

\section{Autonomy}

Among the codes for autonomy, approximately half were negative (19) and the other half positive (16). FAMILY contributed 6 instances of positive autonomy, comprising different categories of family members. However, TEACHERS are the most prominent contributors of positive autonomy. They feature in the roles of liberator and advisor. Liberator dominates, with 13 occurrences, exemplified by the following quotes:

In Grade R my teacher liked to ask us to do anything we are good at just for fun. Others would sing, others do comedy but I always did dance because it was the only thing I could do better than anything. (essay 6)

My art teacher motivated me to think out of the box. [...] This lead me to trying complete different mediums and using different materials such as painting, charcoal, sculpture with clay and plaster of Paris [...] (essay 12).

... as my teacher Mr Ntuli used to say and I quote "life is all about choices," "there are many ways to kill a cat" and "I can teach how to go to Marabastad but not how to come back" those were his usual three quotes meaning the same thing. I sticked on to them and 
made the right choices, life is full of options choose whatever choice works for you (essay 32)

Nineteen instances of negative autonomy were recorded. TEACHERS and THERAPISTS are the most salient categories of significant others who contribute towards negative autonomy (14 out of the 19 items in the category), featuring in thee sponsor identity roles: bully, suppressor and bureaucrat. Bureaucrat elicited the highest frequency of codes (12 times out of the total of 19).

It is interesting to note that almost all instances of negative autonomy originate in high school, as exemplified by the following excerpts:

Unfortunately, during high school I became extremely discouraged to read as we were forced to read reading materials which I had no interest in whatsoever. Prescribed books such as novels and Shakespearean plays were presented to us, as well as anthologies of poetry .... I was so uninterested in these reading materials that I stopped reading in a whole, even materials which were interesting to me. I was discouraged and dislike the English subject immensely. (essay 9)

Going on to high school, reading became a pain, when Shakespeare was first introduced. I till this very day do not understand why it is necessary for the 21st century pupils to read something so very boring and old fashioned. Too few it may have been fun but to most it was pointless and something we had to do just to pass the year. (essay 33)

Over the years my feelings toward the subject escalated. The introduction to comprehension articles and reading was miserable because I could not understand the importance of them. I started becoming less motivated to understand and learn in the English classes. (essay 52)

These quotations support research findings that opportunities to make choices tend to decrease in high school. Since research has found that motivation is enhanced when students have opportunities to make choices (Moller, Deci and Ryan 2006), it is ironic that when students approach adolescence, and are developmentally more able to evaluate options, they are given fewer opportunities to apply this ability (Anderman and Anderman 2010). 


\section{Summary of findings}

Among the three psychological needs that enhance motivation, relatedness is the most salient in the essay corpus. A possible reason is that feelings of relatedness comprise the earliest triggers of motivation to learn, and young children's experiences of these activities are predictors of intrinsic motivation to engage in literacy activities, and to feel efficacious in performing such activities. These dispositions are likely to be transferred from the home domain to the school domain later in life, and to enhance feelings of competence, which are indispensable for achieving mastery. Although feelings of competence primarily arise in contexts where a learner perceives a measure of freedom and personal control (autonomy), autonomy on its own does not seem to be psychologically as salient as the other two needs, and especially the absence of autonomy (controlling environments) does not receive much prominence in the narratives. One explanation is that the essay prompt emphasised 'significant' literacy experiences, and that ideas of autonomy were not perceived to be relevant. Figure 3 summarises the students' construction of contributions by significant others to feelings of autonomy, competence and relatedness:

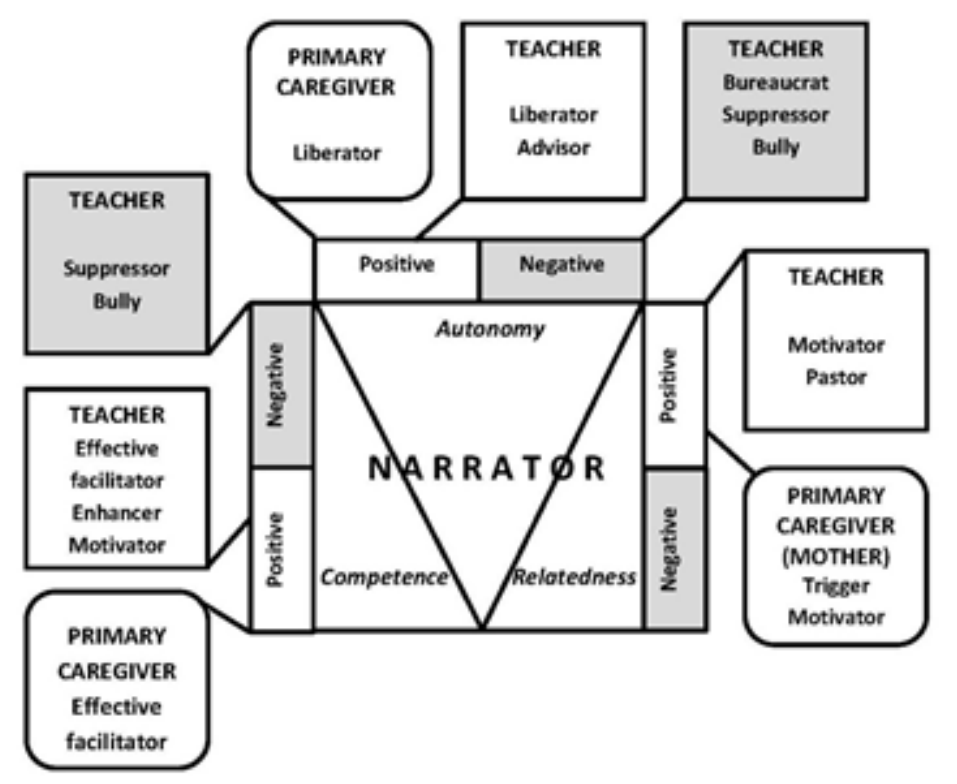

Figure 3: Interrelationships between the sponsor identities of significant others in relation to the narrators' feelings of autonomy, competence and relatedness 
Figure 3 explicates that TEACHERS and PRIMARY CAREGIVERS play the most significant role in enhancing children’s/learners' feelings of autonomy, competence and relatedness.

In terms of autonomy TEACHERS dominate the scene, and are construed as liberators who provide choices, and advisors who give judicious advice. In a number of instances TEACHERS are construed to inhibit literacy acquisition through actions of control (bureaucrats), restraint and prevention (suppressors), and even coercion and intimidation (bullies). TEACHERS are also the primary sponsors of self-efficacy (competence) by expressing confidence in the learner's ability (motivators), helping to promote learning by setting appropriate goals (effective facilitators), and assisting learners to exceed expectations (enhancers). Although PARENTS are construed as the primary sponsors of relatedness, TEACHERS are important extensions of PARENTS through encouraging the learners to take part in activities and to improve their performance (motivators) as well as taking care of their personal needs (pastors). These findings confirm findings by Wentzel (1996), that a 'caring' TEACHER is associated with democratic interaction styles and positive encouragement. In the corpus there is little evidence of TEACHERS who are indifferent to learners.

PARENTS (mostly MOTHERS) and other PRIMARY CAREGIVERS are construed to contribute positively to autonomy and competence, and relatedness in particular. Their involvement is especially important early in life, while engaging with their small children in pre-literacy activities. In such contexts the primary caregiver assumes the role of a literacy trigger. Relatedness in pre-literacy contexts is also closely connected to autonomy, in that children are usually offered choices in terms of the books they read and the literacy activities they prefer to engage in, which is conducive to converting extrinsic motivation to intrinsic motivation. By providing choices primary caregivers act as liberators. PRIMARY CAREGIVERS are occasionally construed as sponsors of competence, when setting realistic goals, providing opportunities for learning, and rewarding achievement in an appropriate way (effective facilitators). These findings resonate with Pomeranz, Grolnick and Price's (2005) description of 'parent involvement'. Pomeranz et al. (2005) state that parent involvement manifests in activities such as reading with children, but also in showing interest in their lives by attending school events, help 
with schoolwork at home or talk about children's school days with them, and showing excitement about children's successes. These activities contribute both to feelings of competence and a sense of relatedness between parents and children. Research has shown that adolescents who saw their PARENTS as high on involvement, structure and autonomy support (authoritative) tended to view themselves as competent (Anderman and Anderman 2010).

\section{Justification and suggestions for reform}

I conclude the article by indicating aspects of the current curriculum for Literacies in Education that already address motivational support by significant adults (raised by the students), and provide some additional suggestions for curriculum review.

Feeling competent is particularly important in academic literacy classes in the faculty where the research was undertaken. Although there are a limited number of instances of negative competence in the corpus, incompetence feedback is portrayed as extremely damaging to motivation, especially when the remarks are personal (not task specific). A strategy that was implemented in the faculty to reduce feelings of incompetence is to assign students from all proficiency levels to the same academic literacy classes, irrespective of the score they obtained on a standardised academic literacy test. To facilitate competence for those who obtained low scores additional tutorial classes are offered, as well as more rigorous scaffolding is introduced. Another competence-boosting strategy included in the existing module is the extensive use of model texts, not only in the syllabus theme on literacy narratives, but throughout the curriculum. Additional strategies that have been identified to promote feelings of competence include:

- Use feedback that attributes success to effort (Deci and Ryan 2000; Anderman and Anderman 2005). A workshop for lecturers has already been organised by the module coordinator to discuss a system of competence-enhancing feedback that will be applied by all the lecturers.

- Give rewards that indicate to students the progress they have made. In recent research at a tertiary institution, Boakye (2012) established that low performing students benefited more from praise and rewards than high performing students. This finding indicates that deserved praise and appropriate rewards should be directed, in particular, to at risk students in the 
tutorial classes.Competence and relatedness are closely aligned in academic literacy development. Researchers have confirmed that the relationship that children have with their TEACHERS in school is particularly important for those who are at risk of academic failure or dropping out of school (Pianta 1999). This is also true for university students, as demonstrated by Boakye's (2012) research. A current institutional (faculty-wide) measure to foster relatedness, especially among the low achievers who are often from low SES backgrounds, is to limit class sizes to between 30 and 50 students. The role of the lecturer as pastor is strongly emphasised during the induction workshop for academic literacy lecturers held at the beginning of the academic year. Feedback received via the university's standardised student feedback system, indicated that first-year students appreciate the mentorship by their academic literacy lecturer and their peer tutor. After receiving confirmation from the results of this research, we intend to suggest to lecturers particular ways in which to foster relatedness:

- Use 'scaffolded motivational discourse', as advocated by Perry, Turner and Meyer (2006), where the lecturer uses language that focuses on learning and improvement, promoting positive emotions and collaboration.

- Manage collaboration with peers effectively, which may include assigning members with different skills sets to groups. For instance, when doing a multimodal assignment, students with advanced technological skills should be combined with students with strong language skills, and others who can creatively contribute cultural and artistic experiences. However, Boakye's research has indicated that group assignments should be alternated with individual assignments, as some of the students (especially the low-risk students) often prefer to work on their own. Enhancing feelings of competence should not override the provision of choices.

Autonomy was the least frequently occurring psychological trigger of motivation (only 35 coding instances). This is interesting in light of findings by Dörnyei and his colleagues that teachers in Hungary (Dörnyei and Csizér 1998) and Taiwan (Cheng and Dörnyei 2007) considered promoting learner autonomy to be an unimportant motivational strategy in L2 teaching.

However, facilitating learner autonomy cannot be ignored because of its low visibility in the corpus and possible neglect by teachers in two countries where English is a foreign rather than a 
second language. When initially developing the curriculum for Literacies in Education, overt attention was paid to giving choices. Allowing a measure of freedom was regarded to be particularly important in this module, as students in general have low intrinsic motivation to engage with the content of compulsory foundational modules. Currently, the choices are primarily organizational (choosing group members) and to some extent procedural (choosing texts or applications). A brainstorming session with lecturers produced the following suggestions:

- Allow students more often to make choices that relate to their specialisations: Foundation Phase and Further Education and Training (FET) students specializing in languages may prefer to write their literacy histories in the format of a narrative essay, whereas students specialising in Economics and Management Studies or Natural Sciences for the Senior or FET phase may prefer to use an expository (factual), cause and effect or argumentative format.

- Allow more choices of published literacy narratives to read in order to accommodate different personal and ideological identities, for instance narratives written by ethnic minorities, first-generation university graduates (in addition to second-generation graduates), female authors (as well as male authors), and even children.

In conclusion, I wish to stress the importance of general classroom discourse in promoting student motivation to improve academic literacy skills. For this I draw support from the transformative pedagogy suggested by Zammit (2011) for children from low SES backgrounds. The type of transformative pedagogy she proposes encourages teachers to 'disrupt disengaging messages and shift them towards engaging messages' (Zammit 2011:205), embodied in five different 'discourses':

Knowledge: recognising the content every participant brings to class;

Ability: reassuring students that no (literacy) experience is unworthy of being recounted, and thus all students perceive themselves as capable;

Control: $\quad$ sharing the pedagogical space with the lecturer and other students;

Place: $\quad$ experiencing feelings of belonging and ownership of learning;

Voice: developing their own voices in a safe environment. 
These discourses underpin the enhancement of all three basic psychological needs: autonomy

(control and voice), competence (knowledge and ability) and relatedness (place). Not only will motivation be promoted, but also social justice, which constitutes a core value of Bachelor of Education programmes.

\section{References}

Anderman, E.M. \& Anderman, L.H. 2010. Classroom motivation. Columbus, Ohio: Pearson.

Ball, A.F. 2000. Preparing teachers for diversity: Lessons learned from the US and South Africa. In C. Lee, \& P. Smagorinsky (eds.), Worlds of meaning: Vygotskyan perspectives on literacy research, 314-359. Cambridge MA: Cambridge Press.

Bandura, A. 1997. Self-efficacy: The exercise of control. New York: W.H. Freeman.

Barton, S. \& Hamilton, M. 2000. Literacy practices. In D. Barton, M. Hamilton and R. Ivanic (eds.), Situated literacies: Reading and writing in context, 7-15. London: Routledge.

Boakye, N. 2012. A socio-affective approach to improving students' reading comprehension abilities. Manuscript in preparation.

Borg, S. \& Al-Busaidi, S. 2011. Teachers' beliefs and practices regarding learner autonomy. ELT Journal Advance Access. Retrieved from http://eltj.oxfordjournals.org <accessed 10 July 2012>.

Brandt, D. 2004. Literacy in American lives. Cambridge, UK: Cambridge University Press.

Carstens, A. 2012. Using literacy narratives to scaffold academic literacy in the Bachelor of Education: a pedagogical framework. SA Journal for Language Teaching 46(2):9-25.

Carstens, A. \& Alston, L. (in press). Literacy self-narratives as constructions of pre-service teachers' multiliterate and multilingual identities. Multilingual Matters.

Cheng, H. \& Dörnyei, Z. 1998. The use of motivational strategies in language instruction: The case of EFL teaching in Taiwan. Innovation in Language Learning and Teaching 1(1):153-174.

Clark, C. \& Medina, C. 2000. How reading and writing literacy narratives affect preservice teachers' understandings of literacy, pedagogy, and multiculturalism. Journal of Teacher Education 51(1):63-76.

Coffey, M. 2011. Literacy narratives across the curriculum. Master's dissertation, Oregon State University, USA. 
Corkery, C. 2005. Literacy narratives and confidence building in the writing classroom. Journal of Basic Writing 24(1):48-67.

Devereux, L. \& Wilson, K. 2008. Scaffolding literacies across the Bachelor of Education program: An argument for a course-wide approach. Asia-Pacific Journal of Teacher Education 36(2):121134.

DHET (Department of Higher Education and Training). 2011, 15 July. Policy on the Minimum Requirements for Teacher Education Qualifications. Government Gazette. Pretoria: Government Printers.

Dörnyei, Z. \& Csizér. 2007. Ten commandments for motivating language learners: Results of an empirical study. Language Teaching Research 2(3):203-229.

Eldred, J.C. \& Mortensen, P. 1992. Reading literacy narratives. College English 54(5):512-539.

Frost, A., Myatt, J.A. \& Smith, J. 2009. Multiple modes of production in a college writing class. In A. Herrington, K. Hodgson and C. Moran (eds.).,Teaching the new writing. Technology, change and assessment in the $21^{\text {st }}$ century classroom, 181-197. New York: Teachers College Press.

Gardner, R.C. 1985. Social psychology and second language learning: The role of attitudes and motivation. London: Edward Arnold.

Kress, G. \& Van Leeuwen, T. 2006. Reading Images. The Grammar of Visual Design. London: Routledge.

Lea, M. 1994. I thought I could write until I came here: Student writing in higher education. In G. Gibbs (ed.), Improving student learning: Theory and practices, 216-226. Oxford: Oxford Centre for Staff Development,

Lillis, T. \& Scott, M. 2007. Defining academic literacies research: Issues of epistemology, ideology and strategy. Journal of Applied Linguistics 4(1):5-32.

Mgqwashu, E. 2009. On becoming literate in English: A during- and post-apartheid personal story. The Language Learning Journal 37(3):293-303.

Moller, A.C., Deci, E.L. \& Ryan, R.M. 2006. Choice and ego-depletion: The moderating role of autonomy. Personality and Social Psychology Bulletin 32(8):1024-1036.

New London Group. 2000. A pedagogy of multiliteracies: Designing social futures. In B. Cope \& M. Kalantzis, Multiliteracies: Literacy learning and the design of social futures, 9-37. Melbourne: Macmillan. 
Newfield, D. \& Maungedzo, R. 2006. Mobilising and modalising poetry in a Soweto classroom.

English Studies in Africa 49(1):60-92.

Noddings, N. 1992. The challenge to care in schools. Alternative approaches to education. New York: Teachers College Press.

Pajares, F. 1996. Self-efficacy beliefs in academic settings. Review of Educational Research 66(4):543-578.

Perry, N.E., Turner, J.C. \& Meyer, D.K. 2006. Classrooms as context for motivating learning. In P.A Alexander \& P.H. Winne (eds.), Handbook of educational Psychology (2 ${ }^{\text {nd }}$ ed), 327-348. Mahwah, JJ: Lawrence Erlbaum.

Pianta, R.C. 1999. Enhancing relationships between children and teachers. Washington DC: American Psychological Association.

Pomerantz, E, Grolnick, W.S. \& Price, C.E. 2005.The role of parents in how children approach achievement. In A. Elliot \& C. Dweck, Handbook of competence and motivation, 259-278. Nueva York: Guilford Press.

Rodrigues, R. 1982. Hunger of memory: The education of Richard Rodriguez. New York: Bantam.

Ryan, R.M. \& Deci, E.L. 2000. Intrinsic and extrinsic motivations: classic definitions and new directions. Contemporary Educational Psychology 25:56-67.

Ryan, R.M., Stiller, J.D. \& Lynch, J.H. 1994. Representation of relationships to teachers, parents and friends as predictors of academic motivation and self-esteem. Journal of Early Adolescence 14(2):226-249.

Ryan, R.M., Stiller, J.D. 1991. The social contexts of internalization: Parent and teacher influences on autonomy, motivation and learning. In P.R. Pintrich \& M.L. Maehr (eds.), Advances in motivation and achievement: Vol. 7. Goals and self-regulatory processes, 115-149. Greenwich, CT: JAI.

Schunk, D.H. 1991. Self-efficacy and academic motivation. Educational Psychologist 26:207-231.

Soliday, M. 1994. Translating self and difference through literacy narratives. College English 56(5):511-526.

Stefanou, C.R., Perencevich, K.C., DiCintio, M. \& Turner, J.C. 2004. Supporting autonomy in the classroom: Ways teachers encourage student decision making and ownership. Educational Psychologist 39:97-110. 
Stein, P. \& Newfield, D. 2006. Multiliteracies and multimodality in English education in Africa: Mapping the terrain. English Studies in Africa 49(1):1-21.

Street, B. 1995. Academic literacies. In D. Baer, C. Fox \& J. Clay. Challenging ways of knowing in Maths, Science and English, 101-134. Lewes: Falmer Press.

Thesen, L. 2001. Modes, literacies and power: A university case study. Language and Education 14(2/3):132-145.

Turner, J. 2011. Language in the academy: Cultural reflexivity and intercultural dynamics. Bristol, UK: Multilingual Matters.

Urdan, T. \& Turner, J.C. 2005. Competence motivation in the classroom. In A. Elliot \& C. Dweck. Handbook of competence and motivation, 297-317. Nueva York: Guilford Press.

Wentzel, K.R. 1996. Social goals and social relationships as motivators of school adjustment. In J. Juvonen \& K.R. Wentzel (eds.), Social motivation: Understanding children's school adjustment. Cambridge, UK: Cambridge University Press.

Wentzel, K.R. 2005. Peer relationships, motivation, and academic performance at school. Handbook of competence and motivation, 279-296. Nueva York: Guilford Press.

Williams, B.T. 2003. Heroes, rebels, and victims: Student identities in literacy narratives. Journal of Adolescent and Adult Literacy 47(4):342-345.

Zammit, K.P. (2011). Connecting multiliteracies and engagement of students from low SES backgrounds: using Bernstein's pedagogic discourse as a bridge. Language and Education, 25 (3), 203-220.

\section{Corresponding author}

Adelia Carstens

Email: adelia.carstens@up.ac.za 